\title{
16p13.11 microduplication syndrome
}

INSERM

\section{Source}

INSERM. (1999). Orphanet: an online rare disease and orphan drug data base. $16 p 13.11$ microduplication syndrome. ORPHA:261243

16p13.11 microduplication syndrome is a recently described syndrome associated with variable clinical features including behavioral abnormalities, developmental delay, congenital heart defects and skeletal anomalies. 